\title{
Paenibacillus panacisoli sp. nov., a xylanolytic bacterium isolated from soil in a ginseng field in South Korea
}

Correspondence Wan-Taek Im wandra@kaist.ac.kr

\author{
Leonid N. Ten, ${ }^{1,2} \uparrow$ Sang-Hoon Baek, ${ }^{1} \dagger$ Wan-Taek $I m,{ }^{1}$ Myungjin Lee, ${ }^{1}$ \\ Hyun Woo $\mathrm{Oh}^{3}$ and Sung-Taik Lee ${ }^{1}$
}

\begin{abstract}
${ }^{1}$ Department of Biological Sciences, Korea Advanced Institute of Science and Technology, 373-1, Guseong-dong, Yuseong-gu, Daejeon 305-701, Republic of Korea

${ }^{2}$ National University of Uzbekistan, Students town, Tashkent, 700-174, Uzbekistan

${ }^{3}$ Insect Resources Research Center, Korea Research Institute of Bioscience and Biotechnology, 52 Oeun-dong, Yusong-gu, Daejeon 305-333, Republic of Korea
\end{abstract}

The genus Paenibacillus was defined in 1993 after an extensive comparative analysis of $16 \mathrm{~S}$ rRNA gene sequences of 51 species of the genus Bacillus (Ash et al., 1991, 1993). At that time, the genus comprised 11 recognized species, with Paenibacillus polymyxa as the type species. At the time of writing, there are 69 recognized species within the genus Paenibacillus (http://www.bacterio.cict.fr). Members of the genus are aerobic, or facultatively anaerobic, organisms that produce ellipsoidal endospores in swollen sporangia and whose cell walls show structures typical of Gram-positive bacteria. The DNA $\mathrm{G}+\mathrm{C}$ content ranges from 39 to $54 \mathrm{~mol} \%$ and anteiso- $\mathrm{C}_{15: 0}$ is the major cellular fatty acid (Shida et al., 1997a).

During the course of study on the culturable aerobic and facultatively anaerobic bacterial community in soil from a

†These authors contributed equally to the work.

The GenBank/EMBL/DDBJ accession number for the 16S rRNA gene sequence of Gsoil $1411^{\top}$ is $A B 245384$.

An expanded phylogenetic tree based on $16 \mathrm{~S}$ rRNA gene sequences of strain Gsoil $1411^{\top}$ and the type strains of representative members of the genus Paenibacillus is available as a supplementary figure in IJSEM Online. ginseng field in Pocheon Province (South Korea), a large number of bacteria were isolated. In this study, we have characterized one of these isolates, strain Gsoil $1411^{\mathrm{T}}$. Phenotypic, chemotaxonomic and phylogenetic analyses establish the affiliation of this isolate to the genus Paenibacillus. The data obtained also suggest that the isolate represents a novel species of this genus.

Strain Gsoil $1411^{\mathrm{T}}$ was originally isolated from soil from a ginseng field. The soil sample was suspended in $50 \mathrm{mM}$ phosphate buffer $(\mathrm{pH} 7 \cdot 0)$ and serial ten-fold dilutions of the suspension were spread on modified R2A agar plates (per litre: $0.25 \mathrm{~g}$ tryptone, $0.25 \mathrm{~g}$ peptone, $0.25 \mathrm{~g}$ yeast extract, $0 \cdot 125 \mathrm{~g}$ malt extract, $0 \cdot 125 \mathrm{~g}$ beef extract, $0 \cdot 25 \mathrm{~g}$ Casamino acids, $0 \cdot 25 \mathrm{~g}$ soytone, $0 \cdot 5 \mathrm{~g}$ glucose, $0 \cdot 3 \mathrm{~g}$ soluble starch, $0 \cdot 2 \mathrm{~g}$ xylan, $0 \cdot 3 \mathrm{~g} \mathrm{C}_{3} \mathrm{H}_{3} \mathrm{NaO}_{3}, 0 \cdot 3 \mathrm{~g} \mathrm{~K}_{2} \mathrm{HPO}_{4}, 0 \cdot 05 \mathrm{~g}$ $\mathrm{MgSO}_{4}, 0.05 \mathrm{~g} \mathrm{CaCl}_{2}, 15 \mathrm{~g}$ agar). The plates were incubated at $30^{\circ} \mathrm{C}$ for 1 month. Single colonies on the plates were purified by transferring them onto new plates and they were incubated again on modified R2A or half-strength modified R2A. The purified colonies were tentatively identified by partial sequencing of the 16S rRNA gene (Im et al., 2005). Strain Gsoil $1411^{\mathrm{T}}$ was one of the isolates which appeared on the modified R2A agar plates under aerobic conditions. It 
was routinely cultured on $\mathrm{R} 2 \mathrm{~A}$ agar at $30{ }^{\circ} \mathrm{C}$ and maintained as a glycerol suspension $(20 \%, \mathrm{w} / \mathrm{v})$ at $-70^{\circ} \mathrm{C}$.

For phylogenetic analysis of strain Gsoil $1411^{\mathrm{T}}$, DNA was extracted using a genomic DNA extraction kit (Core Biosystem), the 16S rRNA gene was amplified by PCR and sequencing of the purified PCR product was carried out according to Kim et al. (2005). The full 16S rRNA gene sequences were compiled using SeqMan software (DNASTAR). The 16S rRNA gene sequences of related taxa were obtained from the GenBank database. Multiple alignments were performed by using CLUSTAL_X (Thompson et al., 1997). Gaps were edited in the BIOEDIT program (Hall, 1999). Evolutionary distances were calculated using the Kimura two-parameter model (Kimura, 1983). Phylogenetic trees were constructed by using the neighbour-joining method (Saitou \& Nei, 1987) and the maximum-parsimony method (Fitch, 1971) using the MEGA3 program (Kumar et al., 2004), with bootstrap values based on 1000 replications (Felsenstein, 1985).

The 16S rRNA gene sequence of strain Gsoil $1411^{\mathrm{T}}$ was a continuous stretch of $1487 \mathrm{bp}$. Comparative 16S rRNA gene sequence analyses showed that strain Gsoil $1411^{\mathrm{T}}$ is phylogenetically affiliated to species of the genus Paenibacillus. The phylogenetic tree based on the neighbour-joining algorithm (Fig. 1) showed that strain Gsoil $1411^{\mathrm{T}}$ appeared within the genus Paenibacillus, but occupied a distinct phylogenetic position (an expanded phylogenetic tree is available as Supplementary Fig. S1 in IJSEM Online). Species found to be closely related to strain Gsoil $1411^{\mathrm{T}}$ were Paenibacillus xylanilyticus XIL14 ${ }^{\mathrm{T}}$, Paenibacillus illinoisensis JCM $9907^{\mathrm{T}}$, Paenibacillus pabuli NCIMB $12781^{\mathrm{T}}$ and Paenibacillus amylolyticus NRRL NRS $-290^{\mathrm{T}}$ with $16 \mathrm{~S}$ rRNA gene sequence similarity levels of $95 \cdot 7,95 \cdot 2,94 \cdot 8$ and $94 \cdot 2 \%$, respectively.

Gram reaction testing was performed by the non-staining method as described by Buck (1982). Cell morphology was observed under a Nikon light microscope at $\times 1000$ magnification, with cells grown for 3 days at $30^{\circ} \mathrm{C}$ on
R2A agar. Catalase and oxidase tests were performed as outlined by Cappuccino \& Sherman (2002). For single carbon source assimilation studies, we used a defined liquid medium plus basal salt medium containing (per litre): $1.8 \mathrm{~g}$ $\mathrm{K}_{2} \mathrm{HPO}_{4}, 1.08 \mathrm{~g} \mathrm{KH}_{2} \mathrm{PO}_{4}, 0.5 \mathrm{~g} \mathrm{NaNO}_{3}, 0.5 \mathrm{~g} \mathrm{NH}_{4} \mathrm{Cl}, 0.1 \mathrm{~g}$ $\mathrm{KCl}, 0 \cdot 1 \mathrm{~g} \mathrm{MgSO}_{4}$ and $0.05 \mathrm{~g} \mathrm{CaCl}_{2}$. To this medium, a vitamin solution (Widdel \& Bak, 1992), trace element solution SL-10 (Widdel et al., 1983) and selenite/tungstate solution (Tschech \& Pfennig, 1984) were added and the $\mathrm{pH}$ of the medium was adjusted to $6 \cdot 8$. This liquid medium was aliquoted $(0 \cdot 24 \mathrm{ml})$ into 96 -well trays and filter-sterilized carbon sources $(0 \cdot 1 \mathrm{ml})$ were added to each well (individually at $0 \cdot 1 \%, w / v)$. Growth in the 96 -well plates was examined visually after incubation at $30^{\circ} \mathrm{C}$ for 7 days. Negative control wells did not contain any added carbon source. A positive control culture was grown in a well containing R2A medium. Fermentative acid production and oxidative acid production from carbohydrates were tested by growth in O-F basal medium with bromothymol blue (Atlas, 1993) supplemented with $1 \%$ carbohydrate [softagar stabs with (fermentative) and without (oxidative) sterile mineral oil overlay]. The $\mathrm{O}-\mathrm{F}$ medium tubes were incubated at $30^{\circ} \mathrm{C}$ for 5 days. Tests for acid production from carbohydrates and some other phenotypic characteristics, as given in the species description below, were determined with API 20E galleries according to the manufacturer's instructions (bioMérieux). Anaerobic growth was tested in serum bottles with the addition of thioglycolate $\left(1 \mathrm{~g} \mathrm{l}^{-1}\right)$ to R2A broth and substituting the upper air layer with nitrogen gas. A test for anaerobic nitrate reduction, as the final electron acceptor, was performed in serum bottles with the addition of thioglycolate $\left(1 \mathrm{~g} \mathrm{l}^{-1}\right)$ to R2A broth and substituting the upper air layer with nitrogen gas, while nitrate was added as $\mathrm{KNO}_{3}$ at concentrations of $10 \mathrm{mM}$. Aerobic nitrate reduction was later confirmed by inoculations, in each case, into three serum bottles $(25 \mathrm{ml})$ containing $12 \mathrm{ml} \mathrm{R} 2 \mathrm{~A}$ media, while nitrate was added as $\mathrm{KNO}_{3}$ at concentrations of $10 \mathrm{mM}$. Reduction of nitrate and nitrite was monitored by ion chromatography (model 790 personal IC; Metrohm) equipped with a conductivity detector and anion exchange

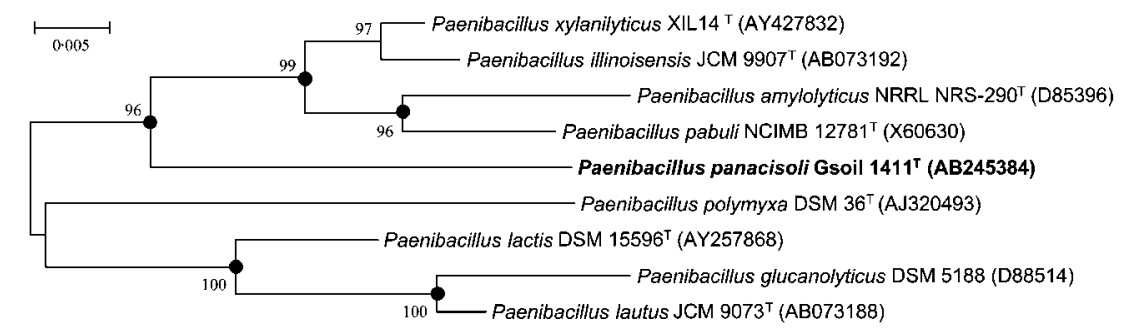

Fig. 1. Comparative analysis of the $16 \mathrm{~S}$ rRNA gene sequences of strain Gsoil $1411^{\top}$ and the type strains of phylogenetically related representatives of the genus Paenibacillus based on the neighbour-joining method. Bootstrap values (expressed as percentages of 1000 replications) greater than $80 \%$ are shown at branch points. Dots indicate that the corresponding nodes were also recovered in the tree generated with the maximum-parsimony algorithm. Bar, 0.005 substitutions per nucleotide position. 
column (Metrosep Anion Supp 4; Metrohm). Tests for degradation of DNA (DNase agar Scharlau by flooding plates with $1 \mathrm{M} \mathrm{HCl}$ ), casein, chitin, starch (Atlas, 1993), lipid (Kouker \& Jaeger, 1987), xylan and cellulose (Ten et al., 2004) were performed and evaluated after 7 days. Growth at different temperatures $\left(4,15,25,30,37,42\right.$ and $\left.45^{\circ} \mathrm{C}\right)$ and various $\mathrm{pH}$ values $(\mathrm{pH} 4 \cdot 0-10 \cdot 0$ at intervals of $0.5 \mathrm{pH}$ units) was assessed after 5 days incubation. Salt tolerance was tested on R2A medium supplemented with $1-10 \%(\mathrm{w} / \mathrm{v}) \mathrm{NaCl}$ after 5 days incubation. Growth on nutrient agar, trypticase soy agar (TSA) and MacConkey agar was also evaluated at $30^{\circ} \mathrm{C}$.

Cells of strain Gsoil $1411^{\mathrm{T}}$ were Gram-positive, motile rods that formed oval spores that lay subterminally in swollen sporangia. Peritrichous flagella were observed (Fig. 2). After 1 day on R2A, colonies were $0.5-1.0 \mathrm{~mm}$ in diameter, convex, irregular, undulate, non-glossy and slightly yellowish. On R2A agar, the optimum temperature for growth was $37^{\circ} \mathrm{C}$. Strain Gsoil $1411^{\mathrm{T}}$ showed oxidase and catalase activity and reduced nitrate to nitrite. Physiological characteristics that differentiate strain Gsoil $1411^{\mathrm{T}}$ from its closest phylogenetic relatives, $P$. xylanilyticus, $P$. illinoisensis, P. amylolyticus and P. pabuli, are listed in Table 1.

For the measurement of $\mathrm{G}+\mathrm{C}$ content of the chromosomal DNA, genomic DNA was extracted and purified as described by Moore \& Dowhan (1995) and enzymically degraded into nucleosides. The $\mathrm{G}+\mathrm{C}$ content of DNA was then determined as described by Mesbah et al. (1989) using reverse-phase HPLC. Isoprenoid quinones were extracted with chloroform/methanol $(2: 1, \mathrm{v} / \mathrm{v})$, evaporated under vacuum conditions and reextracted in $n$-hexane/water $(1: 1$, $\mathrm{v} / \mathrm{v})$. The crude quinone in $n$-hexane was purified using SepPak Vac Cartridges Silica (Waters) and subsequently analysed by HPLC, as described by Hiraishi et al. (1996). Cellular fatty acids were analysed following growth on R2A for 2 days. The cellular fatty acids were saponified, methylated and extracted according to the protocol of the Sherlock Microbial Identification System (MIDI). The fatty

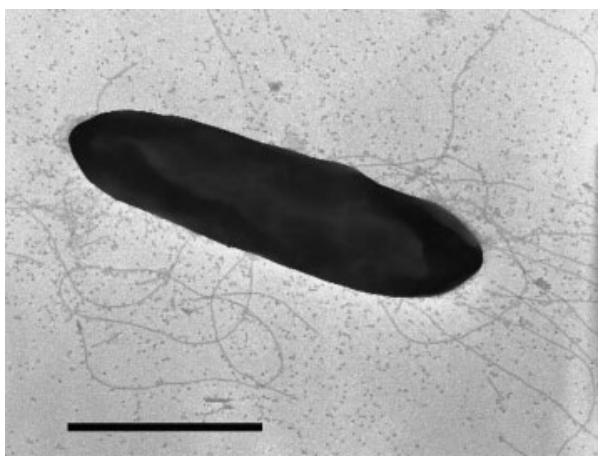

Fig. 2. Negatively stained transmission electron micrograph of a single cell of strain Gsoil $1411^{\top}$, showing peritrichous flagella. Bar, $1 \mu \mathrm{m}$.
Table 1. Differential phenotypic characteristics of strain Gsoil $1411^{\top}$ and the type strains of phylogenetically related Paenibacillus species

Strains: 1, Gsoil $1411^{\mathrm{T}}$; 2, P. xylanilyticus $\mathrm{XIL}_{14}{ }^{\mathrm{T}}$ (data from Rivas et al., 2005); 3, P. illinoisensis NRRL NRS-1356 ${ }^{\mathrm{T}}$ (Shida et al., 1997b); 4, P. pabuli NRRL NRS-924 ${ }^{\mathrm{T}}$ (Shida et al., 1997b); 5, P. amylolyticus NRRL NRS-290 (Shida et al., 1997a). All strains are positive for catalase activity and acid production from L-arabinose and D-mannitol, but are negative for citrate and L-malate utilization. All produce ellipsoidal or oval spores in swollen sporangia. +, Positive; -, negative; V, variable; ND, no data; $\mathrm{W}$, weakly positive.

\begin{tabular}{|lccccc|}
\hline Characteristic & $\mathbf{1}$ & $\mathbf{2}$ & $\mathbf{3}$ & $\mathbf{4}$ & $\mathbf{5}$ \\
\hline Growth: & & & & & \\
$\quad$ At pH $5 \cdot 6$ & + & - & + & + & + \\
In $5 \%(\mathrm{w} / \mathrm{v}) \mathrm{NaCl}$ & + & $\mathrm{ND}$ & - & $\mathrm{V}$ & - \\
At $50{ }^{\circ} \mathrm{C}$ & - & - & + & - & - \\
Oxidase & + & - & - & - & - \\
Nitrate reduction & + & - & - & - & + \\
Indole production & - & - & $\mathrm{ND}$ & - & - \\
Voges-Proskauer reaction & - & - & - & $\mathrm{ND}$ & - \\
Hydrolysis of: & & & & & \\
$\quad$ Casein & $\mathrm{W}$ & - & $\mathrm{W}$ & $\mathrm{V}$ & $\mathrm{W}$ \\
$\quad$ Gelatin & + & + & + & $\mathrm{ND}$ & + \\
$\quad$ Starch & - & + & + & + & + \\
Assimilation of: & & & & & \\
$\quad$ Acetate & - & $\mathrm{ND}$ & + & + & - \\
$\quad$ Succinate & - & $\mathrm{ND}$ & - & - & - \\
$\quad$ Propionate & - & - & - & $\mathrm{ND}$ & - \\
Acid production from: & & & & & \\
$\quad$ D-Rhamnose & - & + & - & $\mathrm{ND}$ & - \\
D-Melibiose & + & + & + & $\mathrm{ND}$ & + \\
$\quad$ Sucrose & - & + & - & $\mathrm{ND}$ & + \\
DNA G+C content $(\mathrm{mol} \%)$ & $53 \cdot 9$ & $50 \cdot 5$ & $48 \cdot 0$ & $45 \cdot 0$ & $53 \cdot 0$ \\
& & & & & \\
\hline
\end{tabular}

acids were then analysed by GC (Hewlett Packard 6890) using the Microbial Identification software package (Sasser, 1990).

The DNA G+C content of strain Gsoil $1411^{\mathrm{T}}$ was $53.9 \mathrm{~mol} \%$, which lies within the range of values reported for members of the genus Paenibacillus. Affiliation of Gsoil $1411^{\mathrm{T}}$ to the genus Paenibacillus was also supported based on analysis of the respiratory quinone system; the majority of species in the genus have MK-7 as the major quinone (Shida et al., 1997a). The fatty acid profile of isolate Gsoil $1411^{\mathrm{T}}$ is given in Table 2 and is compared with those of the type strains of phylogenetically related Paenibacillus species. Anteiso-branched $\mathrm{C}_{15: 0}$, the major fatty acid found in members of the genus Paenibacillus (Shida et al., 1997a), was also the major fatty acid component of strain Gsoil $1411^{\mathrm{T}}$, comprising $44.8 \%$ of the total. However, some qualitative and quantitative differences in fatty acid content were observed between strain Gsoil $1411^{\mathrm{T}}$ and its phylogenetically closest relatives. The second most abundant fatty acid in strain Gsoil $1411^{\mathrm{T}}$ was iso- $\mathrm{C}_{16: 0}$, comprising $20 \cdot 2 \%$ of the 
Table 2. Cellular fatty acid profile (\%) of strain Gsoil $1411^{\top}$ and the type strains of phylogenetically related species of the genus Paenibacillus

Strains: 1, Gsoil $1411^{\mathrm{T}}$; 2, P. xylanilyticus $\mathrm{XIL14}^{\mathrm{T}}$ (data from Rivas et al., 2005); 3, P. illinoisensis NRRL NRS- $1356^{\mathrm{T}}$ (Shida et al., 1997b); 3, P. pabuli NRRL NRS-924 ${ }^{\mathrm{T}}$ (Shida et al., 1997a); 4, P. amylolyticus NRRL NRS-290 ${ }^{\mathrm{T}}$ (Shida et al., 1997b). ND, Not detected; ECL, equivalent chain-length.

\begin{tabular}{|c|c|c|c|c|c|}
\hline Fatty acid & 1 & 2 & 3 & 4 & 5 \\
\hline \multicolumn{6}{|l|}{ Saturated: } \\
\hline $\mathrm{C}_{14: 0}$ & ND & $3 \cdot 9$ & $2 \cdot 0$ & $0 \cdot 7$ & $2 \cdot 9$ \\
\hline$C_{15: 0}$ & $2 \cdot 8$ & $\mathrm{ND}$ & $1 \cdot 0$ & $0 \cdot 1$ & $0 \cdot 5$ \\
\hline$C_{16: 0}$ & $9 \cdot 4$ & $16 \cdot 6$ & $24 \cdot 7$ & $10 \cdot 1$ & $12 \cdot 8$ \\
\hline $\mathrm{C}_{18: 0}$ & $1 \cdot 1$ & ND & ND & $\mathrm{ND}$ & ND \\
\hline \multicolumn{6}{|l|}{ Unsaturated: } \\
\hline $\mathrm{C}_{16: 1} \omega 11$ & ND & $8 \cdot 1$ & ND & $\mathrm{ND}$ & $0 \cdot 1$ \\
\hline \multicolumn{6}{|l|}{ Branched-chain: } \\
\hline iso- $\mathrm{C}_{14: 0}$ & $6 \cdot 9$ & $2 \cdot 3$ & $1 \cdot 8$ & $0 \cdot 7$ & $2 \cdot 3$ \\
\hline iso- $\mathrm{C}_{15: 0}$ & $5 \cdot 0$ & $7 \cdot 1$ & $1 \cdot 5$ & $2 \cdot 2$ & $2 \cdot 0$ \\
\hline iso- $\mathrm{C}_{16: 0}$ & $20 \cdot 2$ & $4 \cdot 7$ & $6 \cdot 3$ & $4 \cdot 8$ & $9 \cdot 0$ \\
\hline iso- $\mathrm{C}_{17: 0}$ & $2 \cdot 1$ & $4 \cdot 5$ & $1 \cdot 4$ & $1 \cdot 3$ & $3 \cdot 5$ \\
\hline anteiso- $\mathrm{C}_{15: 0}$ & $44 \cdot 8$ & $47 \cdot 9$ & $56 \cdot 6$ & $73 \cdot 7$ & $46 \cdot 2$ \\
\hline anteiso- $\mathrm{C}_{17: 0}$ & $5 \cdot 6$ & $4 \cdot 9$ & $4 \cdot 9$ & $4 \cdot 1$ & $2 \cdot 2$ \\
\hline \multicolumn{6}{|l|}{ Unknown:* } \\
\hline ECL $14 \cdot 966$ & $2 \cdot 1$ & ND & ND & ND & ND \\
\hline
\end{tabular}

*The unknown fatty acids have no name listed in the peak library file of the MIDI system and therefore cannot be identified.

total. This value is much higher than that reported for the reference species tested (Table 2). We also found slight differences in the proportions of the other fatty acids.

All characteristics determined for strain Gsoil $1411^{\mathrm{T}}$ are in accordance with those of the genus Paenibacillus. On the basis of its phylogenetic distance from recognized Paenibacillus species, as indicated by relatively low $16 \mathrm{~S}$ rRNA gene sequence similarities $(<96 \%)$, and specific combination of phenotypic characteristics, it is clear that Gsoil $1411^{\mathrm{T}}$ is not affiliated to any recognized species of this genus. Therefore, on the basis of the data presented, strain Gsoil $1411^{\mathrm{T}}$ is considered to represent a novel species of the genus Paenibacillus, for which the name Paenibacillus panacisoli sp. nov. is proposed.

\section{Description of Paenibacillus panacisoli sp. nov.}

Paenibacillus panacisoli (pa.na.ci.so'li. N.L. n. Panax -acis scientific name of ginseng; L. n. solum soil; N.L. gen. n. panacisoli of soil of a ginseng field).

Cells are Gram-positive, facultatively anaerobic, motile, spore-forming and rod-shaped with a length of approximately $2 \cdot 0-5 \cdot 0 \mu \mathrm{m}$ and a width of $0 \cdot 4-0 \cdot 6 \mu \mathrm{m}$. Spores are oval, subterminal and occur in swollen sporangia. After 1 day on $\mathrm{R} 2 \mathrm{~A}$, colonies are $0 \cdot 5-1.0 \mathrm{~mm}$ in diameter, convex, irregular, undulate, non-glossy and slightly yellowish. Oxidase and catalase reactions are positive. Nitrate is reduced to nitrite. The optimum temperature for growth is $37^{\circ} \mathrm{C}$, the maximum growth temperature is between 42 and $45^{\circ} \mathrm{C}$, and the minimum growth temperature is between 15 and $20^{\circ} \mathrm{C}$. The minimum $\mathrm{pH}$ for growth is between 4.5 and $5 \cdot 0$, the optimum $\mathrm{pH}$ is 6.5 and the maximum $\mathrm{pH}$ is between $8 \cdot 5$ and $9 \cdot 0$. Tolerates $5 \%(\mathrm{w} / \mathrm{v}) \mathrm{NaCl}$, but not $7 \%$. No growth occurs on TSA, MacConkey or nutrient agar. Hydrolyses xylan and casein (weakly), but not chitin, starch, cellulose, DNA or aesculin. Utilizes D-mannose, D-ribose, Dxylose, L-xylose, D-lactose, D-raffinose, gluconate (weakly), glycerol and inulin for growth, but not D-glucose, D-fructose, D-galactose, D-mannose, D-fucose, sucrose, Dtrehalose, ethanol, L-rhamnose, L-sorbose, D-arabinose, Larabinose, D-lyxose, formate, propionate, caprate, maleate, phenylacetate, benzoate, 3-hydroxybenzoate, 4-hydroxybenzoate, malonate, pyruvate, acetate, 3-hydroxybutyrate, valerate, fumarate, salicin, citrate, lactate, malate, succinate, tartrate, glutarate, itaconate, adipate, suberate, oxalate, Dcellobiose, D-maltose, D-melibiose, D-raffinose, D-adonitol, dulcitol, D-sorbitol, D-mannitol, xylitol, inositol, amygdalin, methanol, glycogen, dextran, $\mathrm{N}$-acetyl-D-glucosamine, L-cysteine, glycine, L-iso-leucine, L-leucine, L-lysine, Lmethionine, L-phenylalanine, L-serine, L-tryptophan, Ltyrosine, L-valine, L-alanine, L-arginine, L-asparagine, L-aspartate, L-glutamate, L-glutamine, L-histidine, L-proline or L-threonine. In API 20E tests, positive for gelatin hydrolysis and tryptophan deaminase. Negative for arginine dihydrolase, lysine decarboxylase, ornithine decarboxylase, $\beta$-galactosidase, urease, indole and hydrogen sulfide production, citrate utilization and the Voges-Proskauer reaction. Acid is produced from D-mannitol and weakly from L-arabinose, D-melibiose and amygdalin, but not from inositol, D-sorbitol, L-rhamnose, sucrose or D-glucose. MK7 is the predominant menaquinone. The major fatty acids are anteiso- $\mathrm{C}_{15: 0}$, iso- $\mathrm{C}_{16: 0}$ and $\mathrm{C}_{16: 0}$. The $\mathrm{G}+\mathrm{C}$ content of the genomic DNA is $53 \cdot 9 \mathrm{~mol} \%$.

The type strain, Gsoil $1411^{\mathrm{T}}\left(=\mathrm{KCTC} 13020^{\mathrm{T}}=\mathrm{LMG}\right.$ $23405^{\mathrm{T}}$ ), was isolated from soil of a ginseng field of Pocheon Province, South Korea.

\section{Acknowledgements}

This work was supported by the Brain Pool Program (Grant 031-4-17) funded by the Ministry of Science and Technology and by the $21 \mathrm{C}$ Frontier Microbial Genomics and Application Center Program, Ministry of Science \& Technology (Grant MG05-0101-4-0), Republic of Korea.

\section{References}

Ash, C., Farrow, J. A. E., Wallbanks, S. \& Collins, M. D. (1991). Phylogenetic heterogeneity of the genus Bacillus revealed by comparative analysis of small-subunit-ribosomal RNA sequences. Lett Appl Microbiol 13, 202-206.

Ash, C., Priest, F. G. \& Collins, M. D. (1993). Molecular identification of rRNA group 3 bacilli (Ash, Farrow, Wallbanks and Collins) using 
a PCR probe test. Proposal for the creation of a new genus Paenibacillus. Antonie van Leeuwenhoek 64, 253-260.

Atlas, R. M. (1993). Handbook of Microbiological Media. Edited by L. C. Parks. Boca Raton, FL: CRC Press.

Buck, J. D. (1982). Nonstaining (KOH) method for determination of Gram reactions of marine bacteria. Appl Environ Microbiol 44, 992-993.

Cappuccino, J. G. \& Sherman, N. (2002). Microbiology: a Laboratory Manual, 6th edn. San Francisco: Pearson Education, Inc. and Benjamin Cummings.

Felsenstein, J. (1985). Confidence limit on phylogenies: an approach using the bootstrap. Evolution 39, 783-791.

Fitch, W. M. (1971). Toward defining the course of evolution: minimum change for a specific tree topology. Syst Zool 20, 406-416.

Hall, T. A. (1999). BIOEDIT: a user-friendly biological sequence alignment editor and analysis program for Windows 95/98/NT. Nucleic Acids Symp Ser 41, 95-98.

Hiraishi, A., Ueda, Y., Ishihara, J. \& Mori, T. (1996). Comparative lipoquinone analysis of influent sewage and activated sludge by highperformance liquid chromatography and photodiode array detection. J Gen Appl Microbiol 42, 457-469.

Im, W.-T., Jung, H.-M., Cui, Y.-S., Liu, Q.-M., Zhang, S.-L. \& Lee, S.-T. (2005). Cultivation of the three hundreds of bacterial species from the soil of the ginseng field and mining the novel lineage bacteria. In Proceedings of the International Meeting of the Federation of Korean Microbiological Societies, abstract A035, p. 169. Seoul: Federation of Korean Microbiological Societies.

Kim, M. K., Im, W.-T., Ohta, H., Lee, M. \& Lee, S.-T. (2005). Sphingopyxis granuli sp. nov., a $\beta$-glucosidase producing bacterium in the family Sphingomonadaceae in $\alpha-4$ subclass of the Proteobacteria. J Microbiol 43, 152-157.

Kimura, M. (1983). The Neutral Theory of Molecular Evolution. Cambridge: Cambridge University Press.

Kouker, G. \& Jaeger, K.-E. (1987). Specific and sensitive plate assay for bacterial lipases. Appl Environ Microbiol 53, 211-213.

Kumar, S., Tamura, K. \& Nei, M. (2004). MEGA3: integrated software for molecular evolutionary genetics analysis and sequence alignment. Brief Bioinform 5, 150-163.

Mesbah, M., Premachandran, U. \& Whitman, W. B. (1989). Precise measurement of the $\mathrm{G}+\mathrm{C}$ content of deoxyribonucleic acid by highperformance liquid chromatography. Int J Syst Bacteriol 39, 159-167.
Moore, D. D. \& Dowhan, D. (1995). Preparation and analysis of DNA. In Current Protocols in Molecular Biology, pp. 2-11. Edited by Ausubel, F. M., Brent, R., Kingston, R. E., Moore, D. D., Seidman, J. G., Smith, J. A. \& Struhl, K. New York: Wiley.

Rivas, R., Mateos, P. F., Martınez-Molina, E. \& Velazquez, E. (2005). Paenibacillus xylanilyticus sp. nov., an airborne xylanolytic bacterium. Int J Syst Evol Microbiol 55, 405-408.

Saitou, N. \& Nei, M. (1987). The neighbor-joining method: a new method for reconstructing phylogenetic trees. Mol Biol Evol 4, 406-425.

Sasser, M. (1990). Identification of Bacteria by Gas Chromatography of Cellular Fatty Acids. MIDI Technical Note 101. Newark, DE: MIDI Inc.

Shida, O., Takagi, H., Kadowaki, K., Nakamura, L. K. \& Komagata, K. (1997a). Transfer of Bacillus alginolyticus, Bacillus chondroitinus, Bacillus curdlanolyticus, Bacillus glucanolyticus, Bacillus kobensis, and Bacillus thiaminolyticus to the genus Paenibacillus and emended description of the genus. Int J Syst Bacteriol 47, 289-298.

Shida, O., Takagi, H., Kadowaki, K., Nakamura, L. K. \& Komagata, K. (1997b). Emended description of Paenibacillus amylolyticus and description of Paenibacillus illinoisensis sp. nov., and Paenibacillus chibensis. Int J Syst Bacteriol 47, 299-306.

Ten, L. N., Im, W.-T., Kim, M.-K., Kang, M.-S. \& Lee, S.-T. (2004). Development of a plate technique for screening of polysaccharidedegrading microorganisms by using a mixture of insoluble chromogenic substrates. J Microbiol Methods 56, 375-382.

Thompson, J. D., Gibson, T. J., Plewniak, F., Jeanmougin, F. \& Higgins, D. G. (1997). The CLUSTAL_X windows interface: flexible strategies for multiple sequence alignment aided by quality analysis tools. Nucleic Acids Res 25, 4876-4882.

Tschech, A. \& Pfennig, N. (1984). Growth yield increase linked to caffeate reduction in Acetobacterium woodii. Arch Microbiol 137, 163-167.

Widdel, F. \& Bak, F. (1992). Gram-negative mesophilic sulfate reducing bacteria. In The Prokaryotes, 2nd edn, pp. 3352-3378. Edited by A. Balows, H. G. Trüper, M. Dworkin, W. Harder \& K. H. Schleifer. New York: Springer.

Widdel, F., Kohring, G. \& Mayer, F. (1983). Studies in dissimilatory sulfate-reducing bacteria that decompose fatty acids. III. Characterization of the filamentous gliding Desulfonema limicola gen. nov., sp. nov., and Desulfonema magnum sp. nov. Arch Microbiol 134, 286-294. 